\title{
Chronic Lymphocytic Leukemia with Immunoglobulin Heavy Chain Variable- Region Gene Somatic Hypermutation
}

National Cancer Institute

\section{Source}

National Cancer Institute. Chronic Lymphocytic Leukemia with Immunoglobulin Heavy

Chain Variable-Region Gene Somatic Hypermutation. NCI Thesaurus. Code C37202.

Chronic lymphocytic leukemia characterized by the presence of somatic hypermutation within the immunoglobulin heavy chain gene variable region of neoplastic clones. Patients have a better prognosis as compared to those with unmutated immunog lobulin heavy chain gene variable region rearrangements. 